\title{
Etuaptmumk (Two-Eyed Seeing) and Ethical Space: Ways to Disrupt Health Researchers' Colonial Attraction to a Singular Biomedical Worldview
}

\author{
Moneca Sinclaire, PhD, Annette Schultz, PhD RN, Janice Linton, BA, MLS, Elizabeth McGibbon, \\ PhD RN. \\ Cite as: Sinclaire, M., Schultz, A., Linton, J, \& McGibbon, E. (2021). Etuaptmumk (Two-Eyed Seeing) \\ and Ethical Space: Ways to Disrupt Health Researchers' Colonial Attraction to a Singular Biomedical \\ Worldview. Witness: The Canadian Journal of Critical Nursing Discourse, 3(1), pp 57-72. \\ https://doi.org/ 10.25071/2291-5796.94
}

\begin{abstract}
Indigenous research on Turtle Island has existed for millennia, where knowledge(s) to work with the land and its inhabitants are available for next generations. These knowledge systems exist today but are rarely viewed as valid biomedical 'facts' and so are silenced. When Indigenous knowledge is solicited within health research, the knowledge system is predominantly an 'add-on' or is assimilated into Western understandings. We discuss disrupting this colonial state for nurse researchers. Two concepts rooted in Indigenous teachings and knowledges, Etuaptmumk (Two-Eyed Seeing) and Ethical Space, shed light on ways to disrupt health researchers' attraction to a singular worldview which continues to privilege Western perspectives. Knowledge rooted in diverse knowledge systems is required to challenge colonial relations in health research and practice. A synergy between Etuaptmumk and Ethical Space can support working with both Indigenous and biomedical knowledge systems in health research and enhance reconciliation.
\end{abstract}

Key words: Indigenous Peoples; Nursing and Health Research; Etuaptmumk (Two-Eyed Seeing); Ethical Space; Reconciliation

Indigenous research on Turtle Island has existed for millennia, where knowledge to work with the land and its inhabitants ensures resources, information and processes are available for the next generations. While these knowledge systems exist today, when Indigenous knowledge is solicited within academic research it is often an 'add-on' or is silenced by nonIndigenous people or knowledge systems. Although there are Western research methods focused on working with Indigenous Peoples and their knowledge, such as participatory action research, Indigenous Peoples no longer wish to be an add-on, merely contributing to Westernled research. Rather, Indigenous Peoples wish to have their knowledges and epistemologies respected as valid and equally valued alongside Western knowledge and epistemologies (Kovach, 2009; Smith, 2012). While nurse researchers are beginning to demonstrate 
movement towards this wish, more commonly

the profession draws on - and the field of nursing research primarily produces - evidence that is persistently rooted in the singular worldview of biomedical or Western perspectives. These Eurocentric hegemonic relations tenaciously thrive within healthcare, health research, and nursing.

It is necessary to centrally locate Indigenous voices in research in order to inform where research is conducted and what kinds of research is conducted with, for, and by Indigenous Peoples (Peltier, 2018). Our reliance on biomedically-driven research evidence underlies the many examples of policy-driven health disparities, including inequitable rates of illnesses and compromised health outcomes experienced by Indigenous Peoples. Rather than refining Western research approaches, in this paper we consider moving beyond a singular worldview and invite readers to consider the potential of embracing multiple worldviews when conducting research with Indigenous Peoples. Building bridges between different worldviews and knowledge systems is imperative to disrupt colonial relationships and generate diverse health research evidence that is able to shift health discourses concerning Indigenous Peoples beyond health disparities narratives. The subsequent diversified knowledge-base, inclusive of Indigenous perspectives and knowledge systems, can support reconciliation within healthcare practices and research. Reflecting on ideas presented in this paper, and what they mean for nursing and health research, is an important commitment to reconciliation.

We begin our reflective discussion of health research and reconciliation by locating the authors individually and collectively. We provide contextual highlights relevant to reconciliation and Indigenous Peoples and outline two knowledge systems available to inform health research. We then turn to the central aim of describing two concepts rooted in Indigenous teachings: Etuaptmumk (Two-Eyed Seeing) and Ethical Space. Each concept is described in terms of how it can support disruption of health researchers' attraction to a singular worldview. We conclude with a focus on the nursing profession and the moral responsibility to act.

\section{Locating the Authors}

Over the last three decades the authors have individually worked in diverse capacities within healthcare systems as researchers, clinicians in community and acute care settings, decision makers, and as community-based and postsecondary educators. The lead author, Moneca Sinclaire, who is Nēhinan (Cree), has worked in Indigenous Health since completing her undergraduate degree in nutrition, and lives on Treaty One lands and Métis Nation. She understands that Indigenous research on Turtle Island (North America) has been in existence for millennia and that health is viewed through relationships to the land and relationships one has to self and others. And more importantly, that land-knowledge relationship must be handed down generation to generation. The additional three authors are settlers and allies who work with and for Indigenous Peoples. Annette Schultz is from Alberta with French and German ancestry. She now resides on Treaty One lands and the homeland of the Métis Nation. She is a Professor in the College of Nursing, University of Manitoba. Janice Linton, Indigenous Health Liaison Librarian at the University of Manitoba, is a descendent of Scottish and English ancestry and gratefully lives on Treaty One lands and the homeland of the Métis Nation. Elizabeth McGibbon is a white settler of working-class Irish heritage and a Professor in the Rankin School of Nursing, at St Francis Xavier University, Nova Scotia. She lives in Mi'kma'ki, the ancestral and unceded territory of the Mi'kmaq People. Over the last five years we have collaborated on research about diversifying our ways of knowing about First Nations heart health, moving the narrative beyond the singular dominant perspective of a Western biomedical worldview. 
The Canadian Journal of Critical Nursing Discourse

See it. Speak it. Write it. Change it.

\section{Reconciliation and Indigenous Peoples: Turtle Island}

Historically, Indigenous Peoples have lived on Turtle Island for countless generations, and through respecting their natural laws and ways of knowing, they were a healthy and whole society of people (Dickson \& McNabb, 2009; Durie, 2004; Fontaine, Woods, Forbes, \& Schultz, 2019). Elders, such as Margaret Lavallee, Anishinaabe, from Treaty One territory (Personal Communication, 2016) speak about how Indigenous Peoples were a whole and healthy people that understood, through their language and culture, that their health practices expand beyond the individual self and must include relationships with family, community, and the environment, including plants, animals and the land. Upon arrival of Europeans, historical facts reveal the extreme impact of colonial strategies of displacement, subjugation, and systemic control of Indigenous Peoples and their ways of living. In the Northern region of Turtle Island, when Canada was 'established', the non-Indigenous government of Canada exerted control over First Nations, Métis and Inuit in every aspect of life, including place of residence, education, employment, socioeconomic status, governance, healthcare, and political franchise. Written government documentation of the lives of Indigenous Peoples as told by Indigenous Peoples began in the early 1990s with the establishment of the Royal Commission on Aboriginal Peoples (RCAP). "Based on testimony, experience, and research from many Indigenous Peoples and allies in Canada, the [RCAP] report examined historical events, contemporary realities, Indigenous perspectives, and a vision for the future that would embody restructuring the relationship to reflect respect for Aboriginal nationhood" (Linton \& Ducas, 2017, p. 261).

In response to the RCAP report, the Government of Canada released a Statement of Reconciliation, acknowledging their role in the Indian Residential Schools (IRS) (Gathering Strength: Canada's Aboriginal Action Plan, 1997). Nearly a decade passed before the government announced a commitment for actions to honor former students of the IRS, and their families and communities. In 2008, Prime Minister Stephen Harper publicly spoke to the residential schools' contributions to social problems in many Indigenous communities today. During this decade, mounting pressure for reconciliation action increasingly emerged within a collective consciousness in Canada. In 2015, the Truth and Reconciliation Commission's (TRC) report was released, along with Calls to Action, hereafter referred to as Calls) (TRC, 2015b). Of the 94 Calls, seven are directly related to health, underscoring the need for healthcare providers, researchers, educators, and institutions to consider historical and ongoing structural influences on health status, to expand their worldview of health when working with Indigenous Peoples, and to include Indigenous healers. 'Worldview' here represents the ways that groups of people create knowledge about the world around them, and principles for engaging with this world (Tilburt, 2010). The TRC Calls challenge those of us who work in healthcare and health research to unsilence Indigenous knowledge systems.

\section{Reconciliation and Health Research}

Respect for different ways of
understanding and living is at the core
of any reconciliation activity. The
complexity of entrenching this respect
into action in all that we do should not
be underestimated. We must challenge
and transform the foundational
disrespect for Indigenous ways of
knowing and doing that was used to
justify colonial policies and is
persistently embedded in our laws,
schools, health systems and
unconscious minds. (Smylie 2015 ,
p.261)

Reconciliation within health research starts with accepting the truth of historical and ongoing colonial ways, which were designed to assimilate Indigenous Peoples, but ultimately resulted in acts of genocide (TRC, 2015a). The Indigenous Nurses Association publicly concurred with the TRC's Chair, Justice Murray Sinclair's statement that what happened to 
Indigenous Peoples was nothing short of cultural genocide (Bourque Bearskin, 2016). Examples of historical facts of colonial harms that impact Indigenous Peoples' wellbeing include: genocide in the IRS, where approximately 150,000 children were forceable separated from their parents, and an estimated 4,200 of those children died through murder or neglect. In reality there is no way of knowing the actual number and, in fact, it is likely much higher (TRC). During the Clearing of the Plains, within two years of Treaty Six negotiations, between 15,000 and 20,000 Cree People faced starvation when federal government actions resulted in the swift disappearance of bison herds, ending a healthy way of life that had endured on the Western plains for over 10,000 years (Dashchuk, 2013). The National Post (Hopper, 2018) cited that at the time, Sir John A. MacDonald famously stated "We are doing all we can, by refusing food until the Indians are on the verge of starvation, to reduce the expense". Current facts of ongoing colonization include persistent early death due to oppressions related to the social determinants of health (National Collaborating Center for Indigenous Health, 2018), and the shameful reality that 73 percent of First Nations communities in Canada have drinking water that is at medium or high risk for contamination (Council of Canadians, 2020).

Reconciliation among nurses is rooted in our ethical responsibility and the TRC Calls to name and disrupt systemic anti-Indigenous racism and white privilege that is prevalent within our organizations and in our relations with colleagues. As well, nurses have a responsibility to disrupt the colonization of nursing's intellectual development and continued marginalization of Indigenous knowledges (Brown, Smye, \& Varcoe, 2016; McGibbon \& Mbugua, 2019). This process will require nurses working on Turtle Island to relinquish the mindset of relying overwhelmingly on Western and biomedical constructs. These dominant colonial and white settler foundations of nursing knowledge are still based in positivist and depoliticized notions of individualism (e.g., the "patient" and the patient's nuclear family continue to dominate in nursing textbooks and in clinical care), reductionism (e.g., nursing knowledge should be designed solely on measurable, "objective", quantitative data; lived experience is on the bottom of the evidence validity scale) and managerialism (e.g., dominance of workload measurement, focusing on task completion and efficiency; standardization of practices, procedures and even patients; dominance of technology over relationality). Neutrality claims inherent in biomedical (positivist, reductionist) nursing knowledge development, research, and teachinglearning processes are illogical because nurses are immersed in the same stereotypes as the general Canadian population (e.g., Indigenous Peoples are "savages, alcoholics, uncultured, violent..." (Henry \& Tator, 2006, p. 259). Nursing also continues to be grounded in equality myths that serve to reinforce false beliefs that neutrality and objectivity are not only possible, but desirable. Nursing discourse continues to be largely grounded in the belief that we are all equal and thus have equal opportunities to better ourselves and to improve our quality of life if we try really hard (McGibbon, Malaudsi, Didham, et al., 2013).

The explicit and implicit perpetuation of these beliefs and assumptions remains sustained in systemic structures such as the education, legal, governmental and healthcare systems. As the nursing profession evolved within and alongside colonialist domination, these same beliefs and assumptions are embedded in nursing history and in present-day nursing knowledge and practices, professional codes of ethics, policy and position papers, and institutional nursing policies and procedures. (p. 5)

Embracing Indigenous epistemologies alongside Western, Eurocentric dominance involves meticulous attention to this current hegemony of biomedicine. Working in allyship with Indigenous Peoples is at the core of reconciliation action to unseat the colonialist domination of nursing, and its underpinnings of white settler privilege and supremacy. Allyship becomes central in nursing practice, where we 
enter into a constantly opening and re-opening space as nurses with privileges actively listen to (and actively learn not to silence) the voices of those with whom we are allying ourselves (McGibbon \& Mbugua, 2019) - committing to engaging in education and action about how to ethically work with and integrate Indigenous knowledges.

Ending the dismissal and silencing of Indigenous knowledge systems as less scientific is imperative to advance healthcare to effectively support the wellbeing of Indigenous Peoples (Cornell, 2006). The TRC specifically implores healthcare professionals "to recognize the value of Aboriginal healing practices and use them in the treatment of Aboriginal patients in collaboration with Aboriginal healers and Elders where requested by Aboriginal patients" (TRC, 2015b, p. 3). Respect for Indigenous worldviews and knowledge can only happen when nurses stop dismissing, denigrating or silencing Indigenous voices. A central challenge is to actively disrupt the colonial dominance that is endemic in a narrowly defined evidence-base rooted in biomedical knowledge - one that currently informs healthcare policy, assessments and interventions, and is incapable of addressing the TRC Calls to action because there is minimal truth-telling. Perhaps most importantly, these approaches to do not contribute to unsilencing Indigenous knowledges.

Left unchallenged, when Indigenous Peoples are invited to research tables, a hegemonic relationship persists where Western researchers decide if Indigenous methods are valid, rather than beginning the process with Indigenous methods at the center. We will require unfamiliar ways of approaching and thinking about research as exemplified by questions such as "Evidence according to whom? Evidence according to which worldviews? Evidence according to whose voice?" (McGibbon, Malaudzi, Didham, et al., 2013, p. 6). Indigenous and non-Indigenous scholars have begun to assert the philosophy of TES into health research, such as First Nations Health (2020); Iwama, Marshall, Marshall, and Bartlett (2009); Martin, Thompson, Ballard, and Linton
(2017); Peltier (2018); Wright, Gabel, Ballantyne, et al. (2019); as well as podcasts such as Mi'kmaq Elder Albert Marshall, Drs. Jesse Popp, Andrea Reid and Deborah McGregor's (2020) Dialogue 4: Two-Eyed Seeing \& Beyond. This work lays a foundation, a starting point for Western-focused health researchers who, if willing to acknowledge, value and work with the different knowledge systems, will play a role in decolonizing healthcare systems through generating evidence that informs biomedical knowledge rather than being an "add on" or dismissed to silencing margins.

\section{Two Worldviews and Knowledge Systems}

Indigenous and biomedical worldviews originate in unique systems of knowledge and have divergent approaches to health and health research (Figure 1). Within a colonial nation such as Canada or a context such as healthcare, there are unidirectional relationships between Indigenous Peoples and those residing within the biomedical worldview. Knowledge within colonial contexts tends to remain isolated within each system, with either limited, or more commonly, no sharing of knowledge. The nondominant knowledge system is dismissed and silenced by those immersed in the dominant (i.e., biomedical) knowledge system. Healthcare professionals entrenched in biomedical worldviews are often unable to see or consider benefits brought forth from other worldviews. For example, Indigenous Peoples in Canada have known for millennia that the wellbeing of individuals and communities is linked to broader dynamics beyond individualistic, biomedical approaches to health (de Leeuw, Lindsay, \& Greenwood, 2015). Indigenous Peoples' knowledge systems and worldviews have been radically altered by the arrival of Europeans, and by implication Indigenous Peoples themselves have been seriously fractured (Durie, 2004). They are no longer a whole healthy people, but people whose mental, spiritual, physical and emotional health have been 'broken' by not only colonial history but continually 'fragmented' when seeking health solutions in a system that does not acknowledge that they have different 
ways of understanding health and healing. Alienation of people from their environmentfrom the natural world - may be as closely linked to the host of health problems that beset Indigenous Peoples as the more familiar lifestyle risks of modern living (Dickason \& McNabb, 2009; Durie).

\section{Etuaptmumk and Ethical Space}

Etuaptmumk is a philosophy proposed by Mi'kmaq Elders Albert and Murdena Marshall as a means to bridge Western science knowledge systems and Indigenous knowledge systems (de Leeuw, Lindsay, \& Greenwood, 2015). Ethical Space was originally coined by Roger Poole
(1972), and further developed by Nēhinan (Cree) scholar Willie Ermine (2007): “...ethical space

is formed when two societies, with disparate worldviews, are poised to engage each other, a theoretical space between them is opened" (Ermine, 2007, p. 194). An exploration of these two concepts sheds light on decolonizing approaches for health research to create spaces where Indigenous Peoples, knowledge and worldviews can be reclaimed and elevated to inform healthcare practices and policies. The concepts of Etuaptmumk and Ethical Space are addressed separately, followed by our proposed synergistic relationship of the two concepts.

Figure 1: Biomedical and Indigenous Knowledge Approaches to Health Research

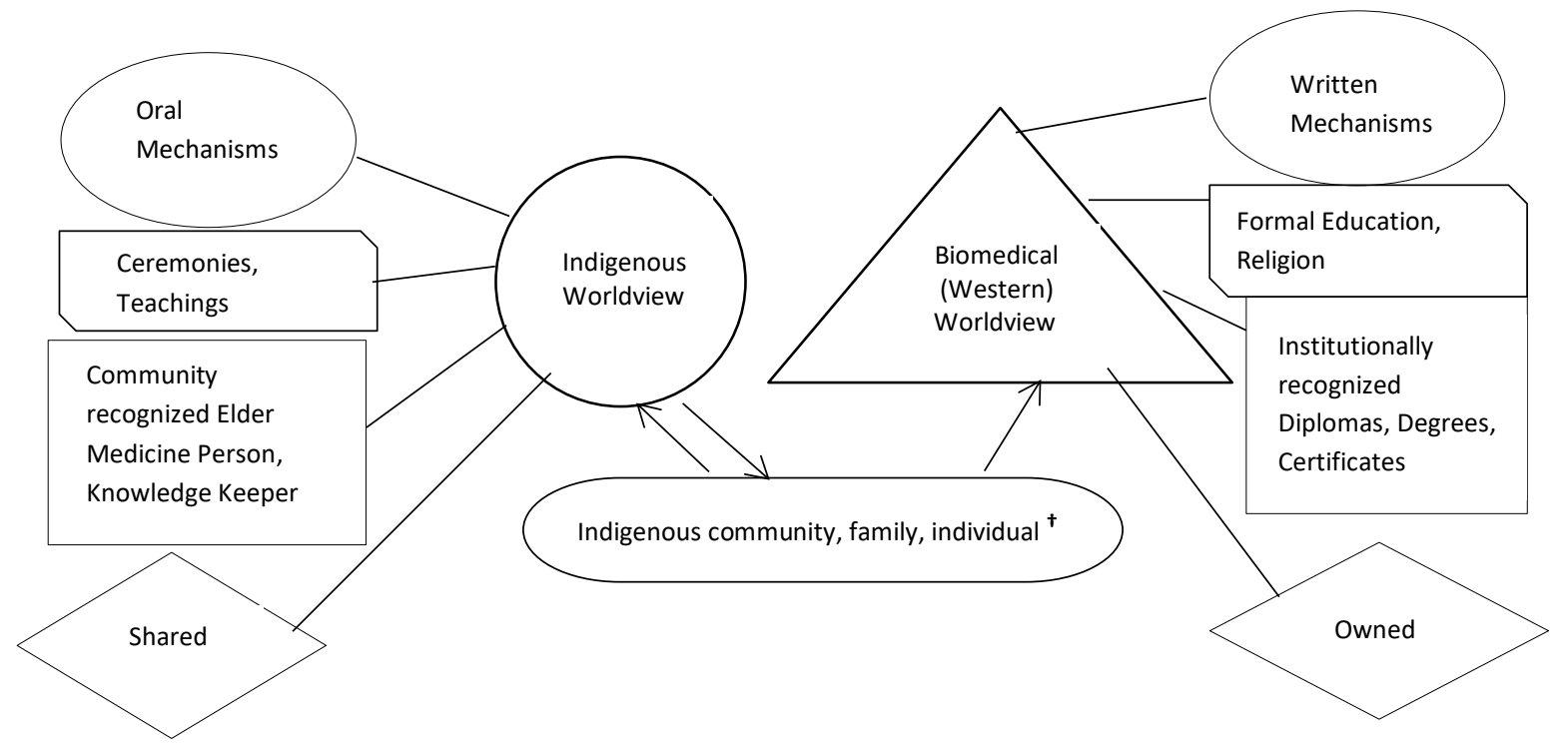

Figure Notes:

${ }^{\dagger}$ Seeking health services

Approach to Knowledge

$\square$ Legitimize Knowledge

$$
\begin{aligned}
& \rightarrow \text { Indicates relationship flow } \\
& \square \text { Transfer of Knowledge } \\
& \diamond \text { Management of Knowledge }
\end{aligned}
$$

At the core of Etuaptmumk (Figure 2), is an acknowledgement of diverse ways of understanding the world, including Indigenous and biomedical perspectives, and seeking respect for both by disrupting the dominance of one over another (Iwama, Marshall, Marshall, \& Bartlett, 2009). Etuaptmumk is philosophical concept and not a research method with prescribed steps. Rather Etuaptmumk guides Indigenous and non-Indigenous people working together to constantly ask themselves if respect for multiple worldviews is stronger within the relationship than a reliance on one viewpoint. Thus, Etuaptmumk is a process that never 


\section{See it. Speak it. Write it. Change it.}

reaches a static endpoint. As well, there is no seeking to merge two knowledge systems into one, nor does it propose pasting bits of Indigenous knowledge onto Western knowledge (Iwama, Marshall, Marshall, \& Bartlett, 2009). Moreover, it does not result in non-Indigenous people somehow developing Indigenous knowledge, which can be used to solve Indigenous Peoples' health issues. What Etuaptmumk can do is invite all involved to work towards acknowledging and respecting multiple divergent knowledge systems which will guide creation of evidence rooted in two ways of knowing to inform practice and policymaking. Thus, it can be a guide to disrupt research with a singular world view by opening one's mind to divergent views such as Indigenous knowledge systems and perspectives (Martin, 2012). In other words, Etuaptmumk challenges health researchers to recognize that the hegemonic biomedical view is not the only choice when it comes to understanding health and engaging in research with Indigenous Peoples.

Figure 2: Visual Representation of Etuaptmumk within the context of Health Research
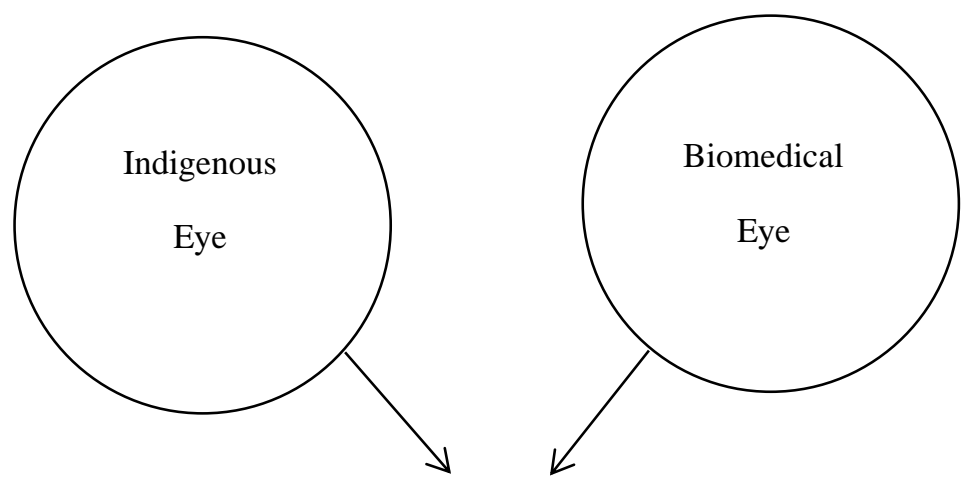

Each eye acknowledges and accepts diversity of perspectives

Etuaptmumk embraces different ways of knowing to motivate people, Indigenous and non-Indigenous alike, so that a better, more whole people rather than a fragmented people can be envisioned, and opportunities, especially for youth, are not compromised (Bartlett, Marshall, \& Marshall, 2012; Miller, 2020). Aspects of both Western and Indigenous ways of knowing about the world are important for Indigenous communities. Drawing on what is useful and relevant from each "eye", both Indigenous and non-Indigenous people can learn to "see through both eyes, seeing" with the strength of both Indigenous and Western knowledge systems for the benefit of all.
Ethical Space, Ermine (2007) claims, is a place where co-creation of future possibilities exists. Ethical Space is not only about finding commonalities but also about working with and understanding strengths and challenges of bringing together divergent worldviews. Through this work we learn how to use diverse knowledges to create workable solutions. In current colonial relationships within healthcare, Turnbull (1997) argues that there is no greater divide than what exists between Western sciences and Indigenous knowledge(s). He suggests that the two systems operate within "different knowledge spaces with different 
devices and strategies for assembling and moving the knowledge and that this third space or ethical space is where knowledge systems can be reframed and re-negotiated (p.557)." As a philosophical landscape, Ethical Space facilitates development of linkages between divergent worldviews that are ethically sustainable, as well as equality of thought amongst diverse communities (Tait, 2008). Ethical Space enables dialogue inclusive of local contextual Indigenous knowledge systems, alongside dominant ways of knowing. These spaces move us forward with actions to promote Indigenous health and reduce our attraction to focusing on disparities (Vukic, Gregory, \& Martin-Meisner, 2012). As Ethical Space emerges, there is an opening for dialogue among people who hold different worldviews (Ermine, Sinclair, \& Jeffrey, 2004). As well, Ethical Space encourages an appreciation of multiplicity of seeing two divergent but equally respected worldviews, where Ethical Space is both created and nurtured (Ermine, 2007).

\section{Synergistic Relations: Bringing Together Etuaptmumk \& Ethical Space}

Etuaptmumk and Ethical Space can guide the cocreation of knowledge, in keeping with
Indigenous traditions that honour the blending of Indigenous and Western understandings of moral governance (Vukic, Gregory, \& MartinMeisner, 2012). Although the two concepts differ, their synergy can catalyze action in the TRC Calls related to health and health-related research. Current approaches to health research remain rooted in colonial practices of privileging biomedical knowledge (the biomedical eye) and silencing Indigenous knowledge (the Indigenous eye). For example, the evidence base informing heart health, and how we collectively identify related concerns, is tenaciously grounded in a narrow focus on heart disease and the physical body (Schultz, Sinclaire, Linton, McGibbon, \& Fisher, 2016). So, how can Indigenous and nonIndigenous people engage in multiple perspectives that will complement each other's strengths? As the TRC Calls suggest, understanding the current health of Indigenous Peoples, including heart health, requires understanding the profound impact of colonization on the lives of Indigenous Peoples (Fontaine, Woods, Forbes, \& Schultz, 2019; Walker, 2015; Vukic, Gregory, \& MartinMeisner, 2012) and cultivation of space to listen to Indigenous knowledges concerning caring for heart health.

Figure 3: Absence of Ethical Space for Engagement: Current Health Research Spaces

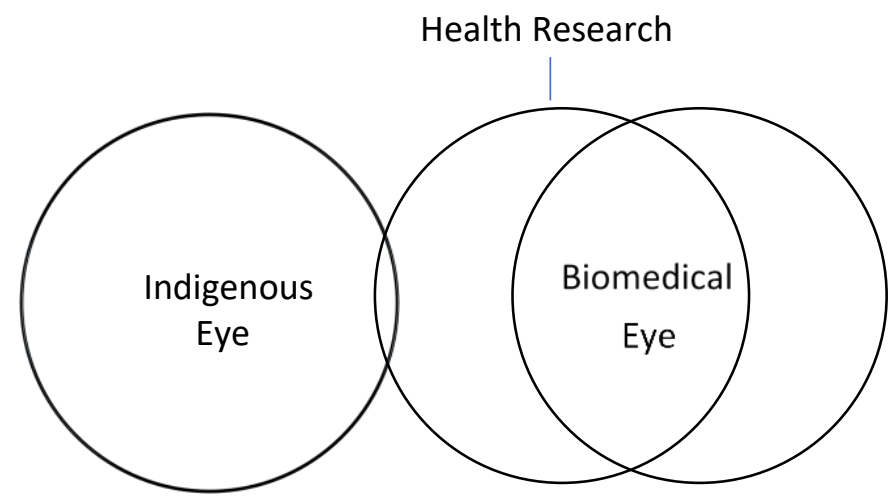




\section{See it. Speak it. Write it. Change it.}

Figure 3 depicts health research (central circle) contexts today, where biomedical worldviews (biomedical eye) dominate health research and there is limited space for Indigenous ways of knowing (Indigenous eye) (Denzin, 2008). Biomedical worldviews and approaches are privileged and there is no overlapping space between the two eyes, which means an Ethical Space for dialogue has not emerged. For healthcare researchers, the absence of Ethical Space can be problematic when they engage with Indigenous Peoples, who bring a different worldview to understanding health and healthcare. With growing recognition of the complex nature of causes and consequences of ill health in Indigenous communities, it is not enough to define and describe health issues through the biomedical eye (Martin, 2012). Rather, it is important to conduct research grounded in Indigenous knowledge systems, where research begins with, for example, Elders/Indigenous community members coming together with non-Indigenous/Indigenous researchers over tea, to support new relationships. If a need for change, a traditional teaching, or experience is raised by an
Indigenous Person, a research idea might flow. But when non-Indigenous people/researchers share tea with the intent to propose a research idea, this process precludes the time required to earn respect, trust, and contribute to the ethical space of patiently waiting for the Indigenous Peoples to lead.

Figure 4 depicts an ideal space for health research, where the biomedical eye and Indigenous eye equally hold space. Ethical relations involve a back and forth, give and take of knowledges between the biomedical and Indigenous worldview. Relational accountability becomes possible, where all parts of the research process evolve in Ethical Space from inspiration to expiration (Smith, 2012). Relational accountability means that those with biomedical and Indigenous worldviews negotiate processes and procedures where Indigenous Peoples have their voices and concerns heard and honoured, and where outcomes include better policies and programs to empower and heal Indigenous Peoples. That is when the TRC Calls to redress colonization will be realized and reconciliation begins to emerge.

Figure 4: Emerged Ethical Space of Engagement: Ideal Health Research Spaces

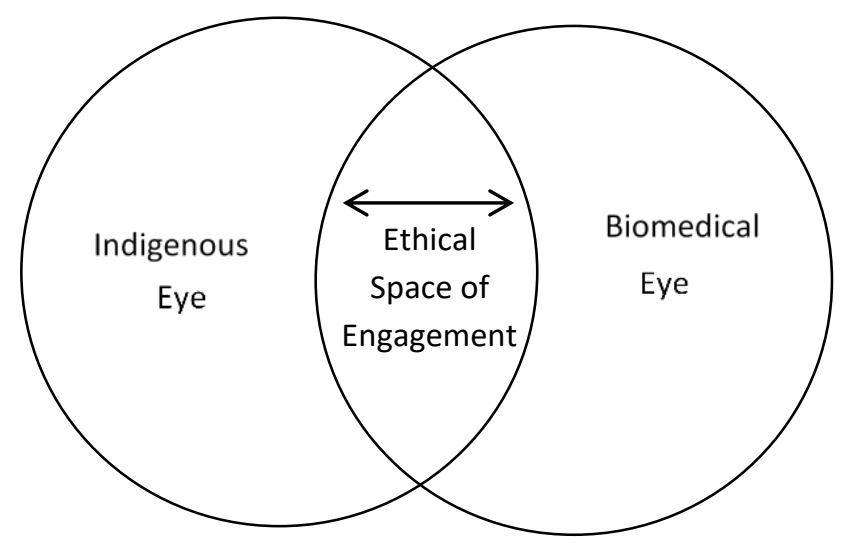


The causes and consequences of ill health within Indigenous communities are complex and intertwined with historical, social, political, economic, and environmental factors. One cannot hope to address these issues without a thorough understanding of the context within which health is situated (Walker, 2015; Goodman, Fleming, Markwich Morrison, Lagimodiere, et al., 2017). When health contexts are understood from both Indigenous and biomedical worldviews (or eyes), guided by Etuaptmumk and Ethical Space of engagement, then new possibilities for change can emerge, strengthened by the evidence base and knowledge repositories from both systems of doing and knowing. The centrality of the health of Indigenous Peoples will no longer be absent or ignored when actions are taken to ensure that Etuaptmumk and Ethical Space are nurtured and maintained.

\section{Nursing, Health Research, and Reconciliation: Disrupting our Relationship with Biomedical Worldviews}

Nursing scholars and educators have room to grow with truth-telling regarding realities of our colonial practices, both historically and currently. Evidence of this process can be found in Symenuk, Tisdale, Bourque Bearskin et al.'s (2020) narrative review that systematically examined nursing's complicity in colonial harms: Indian hospitals, IRS, child apprehension, Missing and Murdered Indigenous Women and Girls, and forced sterilization, to name a few. One of their conclusions was: "The paucity of results during the post-TRC period demonstrates a lack of scholarship in uncovering the truth of nursing's complicity in these systems" (Symenuk et al., p. 84). Advancing our base of evidence will require ending hegemonic constraints of biomedical worldviews shaping nursing research and addressing incomplete epistemologies that inform nursing practice (Reimer Kirkham, Baumbusch, Schultz, \& Anderson, 2007).

Etuaptmumk and Ethical Space philosophical perspectives are necessary to guide nursing and healthcare research in working with Indigenous Peoples and their health. In Box 1, we detail four examples of Etuaptmumk research, where Canadian nurse researchers are working with Indigenous Peoples to begin the work of breaking down the tendency of working solely within the Western worldview. These exemplars were chosen to demonstrate the diversity of research approaches and intentions being guided by Etuaptmumk, and where Canadian nurse researchers are embracing multiple worldviews in guiding research with Indigenous Peoples for Indigenous Peoples.

\section{Box 1: Nurse Researchers Working with Multiple Worldviews}

Hishukish tsawalk (Everything is one, everything is connected): Lynnette Lucas, (Nuu-Chah-Nulth, NCN), Jeff Reading (Mohawk), Pablo Nepomnaschy (Argentina), Charlotte Waddell (Settler), and Scott Venners (Settler). Working with the Nuu-Chah-Nulth Tribal Council and the FN Health Authority in British Columbia, the team used two-eyed seeing to study healthy early life trajectories for Indigenous Peoples, focusing on Indigenous children's development and health. This project is part of a global initiative to reduce adult and child onset chronic disease and foster health and wellness. (Lucas, 2019)

Understanding Aboriginal Children's Pain from a Two-Eyed Seeing Perspective. Margot Latimer (Settler) Sharon Rudderham (Eskasoni FN); Alan Syliboy (Mi'kmaq FN). A question was generated from a community research perspective. The team learned that Aboriginal children are socialized through cultural beliefs and perspectives, and also through the trauma that happened in residential schools, to be quiet about their pain (Dalhousie University School of Nursing, 2017). Using art-based 
findings, these researchers saw the importance of creating a culturally safe space for children in terms of their pain. (Latimer et al., 2014)

Debwewin: The Truth of Our Hearts. Annette Schultz (Settler), Moneca Sinclaire (Nehinan, Cree); Mary Wilson (First Nations Elder). This study was shaped by two-eyed seeing philosophy, to approach heart health of First Nations Peoples in Manitoba. (Full description in this article) (Schultz, Dahl, McGibbon, et al., 2020).

Elevating the Uses of Storytelling Approaches within Indigenous Health Research: A Patient-engaged Scoping Review Study Involving Indigenous Peoples and Settlers. Kendra Rieger (Settler), Sara Gazan (Lakota First Nations), Elders: Sherry Copenace (Ojibways of Onigaming First Nation), Mabel Horton (Nisichawayasihk Cree Nation). The team brings together 20 people, of which 13 are Indigenous; 3 of the leads are Indigenous, and one of the hired research assistants is Indigenous. The study was collaboratively designed and is being conducted respecting Indigenous protocols guided by the two study Elders, and by western methods of scoping reviews. While scoping the literature is part of the work, equally important are teachings about storytelling and Indigenous perspectives of the role of stories. Through these teachings and ceremony, lessons (ways of seeing) will be brought to our review of the academic literature to pose questions about how storytelling is being used and reported by academic literature, which is informing healthcare evidence-bases. (Rieger, et al., 2020)

A further discussion of the research collaborations of Annette Schultz (Settler), Moneca Sinclaire (Nehinan, Cree); Mary Wilson (First Nations Elder), included in Box 1 provides a glimpse of how Etuaptmumk might unfold in a research project. Their study Debwewin: The Truth of Our Hearts, was shaped by an Etuaptmumk philosophy to approach heart health of First Nations Peoples in Manitoba. The study included secondary analysis of health administrative data, and a qualitative component to listen to First Nations people. In the secondary analysis, conversations with Elders and Moneca Sinclaire informed variable selection and interpretation of findings. Qualitative methods changed, based on our relationship with Elder Mary Wilson. This shift resulted in letting go of interviews with First Nations heart health patients and opening to creation of a documentary: Pac-Ow-Tay (Ballantyne, Sinclaire, \& Schultz, 2020). Documentary material was recorded during four gatherings with three Medicine people and two Elders. For one year we gathered to talk about the heart, heart health and healthcare. Stories included teachings about the heart and traditional Indigenous practices and three generations weaving traditional practices with biomedical treatment of heart disease with their family, along with other historical and current day experiences within North American society that shaped their beating hearts.

These academic research approaches are in their infancy, but with time and experience, trust between academic researchers and Indigenous Peoples will grow. As our collective understanding of working within and nurturing Ethical Space grows, our ability to embrace both Indigenous and Western worldviews will mature and relational ties will grow stronger. These strengthened relational ties hold the possibility of accepting gifts within Indigenous worldviews, as our ability to see and unsilence Indigenous knowledges develops. Martin (2012) provides a useful reminder for those who gravitate towards using multiple worldviews to answer our most pressing questions about the health of Indigenous Peoples and communities:

Two-eyed seeing is not about nursing, specifically, nor even about health singularly. It is intended to apply to life itself. It does not offer new methodologies, nor does it offer ideas about the types of knowledge that it 
might generate. Rather, it challenges us (Indigenous and non-Indigenous Peoples alike) to understand the larger dimensions (physical, social, emotional, spiritual) of our knowledge systems and the limitations and challenges that accompany any single approach of viewing the world. The ultimate challenge is to find new and better ways of doing research in order to create a healthier place for our children and our children's children, for Seven Generations forward. (p. 37)

\section{Conclusion}

Reconciliation begins with truth-telling and acknowledgement of the unacknowledged facts that make up the more complete story, which is inclusive of the perspectives and knowledges of those who were harmed. Research that privileges Indigenous knowledges and perspectives is an act of decolonization that can move health discourses about Indigenous Peoples beyond simply comparing Indigenous Peoples' health status with non-Indigenous people, and disrupt disparity narratives. Indigenous knowledges and perspectives informing research will alter the types of questions asked, what information is considered legitimate, and whose perspective sheds understanding on the findings. Embracing Etuaptmumk as a guiding principle within health research will support both Indigenous and nonIndigenous worldviews in working towards becoming equitable and opening possibilities for Ethical Space. A new norm can become one view working with another, replacing colonial relations of dominance by the one view. Integrating and realizing this 'new norm' will come with challenges as most non-Indigenous health practitioners, decision-makers, researchers, and leaders do not understand that their evidence is located within a dominant worldview, nor that other worldviews exist and are valid. Diminished capacity to consider the existence of an alternate worldview shapes their ability to see and respect that Indigenous Peoples have their own practices towards health. A hegemonic relationship remains, rather than a relational association where both 'worldviews' can listen in a respectful manner to one another's views in their approaches to health.

Given the history of healthcare and nursing as colonizing forces, and the inability or lack of interest to acknowledge power dynamics, the result is a context that does not foster trust in the biomedical worldview for Indigenous Peoples (Horrill et al., 2018). With the TRC Calls to action, it is important to constantly think outside the structures of 'us versus them' and to think about how we can move forward in creating frameworks and structures to support reconciliation, even when it feels uncomfortable. Respect for multiple ways of seeing and disrupting our powerful attraction to a singular world-view, are imperative to address the health status and healthcare experiences of Indigenous Peoples. We envision that together Etuaptmumk and Ethical Space creates a foundation to support healthcare drawing on both sets of worldviews and knowledge systems. In Ethical Space, respectful engagement of Indigenous Peoples and non-Indigenous partners shifts relationship dynamics by dismantling colonial dominance and thus supporting possibilities for reconciliation within healthcare. The TRC's Calls explicitly address health, healthcare, and nurses, where each have a responsibility to take action, not only individually, but collectively in the structural, policy realm: "If you are neutral in situations of injustice, you have chosen the side of the oppressor. If an elephant has its foot on the tail of a mouse and you say that you are neutral, the mouse will not appreciate your neutrality" (Bishop Desmond Tutu, pre-1986).

\section{Declaration of Conflicting Interests}

The authors declared no potential conflicts of interest with respect to the authorship and publication of this article.

\section{Funding}

The authors received no financial support for the authorship and publication of this article.

\section{Ethical Permissions}

None Required. 


\section{See it. Speak it. Write it. Change it.}

\section{References}

Ballantyne, S. [Sonia Ballantyne], Sinclaire, M., \& Schultz, A. (January, 2020). Pac-Ow-

Tay (Our Beating Hearts).

[Documentary].

https://youtu.be/FpYWppuKp90

Bartlett, C., Marshall, M., \& Marshall, A. (2012).Two-Eyed Seeing and other lessons learned with co-learning journey of bringing together indigenous and mainstream knowledges and ways of knowing. Journal of Environmental Studies in Science, 2(10).

Bourque Bearskin, R. L. (2016). Through the lens of truth and reconciliation: Next steps. The Canadian Nurse, 112(2), 36.

Browne, A., Smye, V. \& Varcoe, C. (2016). Critical shifting gears: Engaging in critically oriented praxis in neoliberal and neocolonial context. Manuscript in progress.

https://www.sydney.edu.au/nursing/pdfs/c ritical-perspectives/browne-varcoesmye.pdf

Council of Canadians. (2020). Safe water for First Nations. https://canadians.org/fnwater

Cornell, S. (2009). Indigenous Peoples, poverty and self-determination in Australia, New Zealand, Canada and the United States (Contract No.: JOPNA No. 2006-02). Native Nations Institute for Leadership, Management, and Policy-The Harvard Project on American Indian Economic Development.

Dashchuk, J. (2013). Clearing the plains: Disease, politics of starvation, and the loss of Aboriginal life. University of Regina Press.

de Leeuw, S., Lindsay, N.M., \& Greenwood, M. (2015). Introduction: Rethinking determinants of Indigenous Peoples' health in Canada. In S. de Leeuw, N.M. Lindsay, \& M. Greenwood (Eds.), Determinants of Indigenous Peoples' Health in Canada (pp. xi-xxix). Canadian Scholars' Press.

Denzin, N.K., \& Lincoln, Y.S. (2008). Introduction: Critical methodologies and Indigenous inquiry. In N.K. Denzin, Y.S. Lincoln, \& L.T. Smith (Eds.), Handbook of critical and Indigenous methodologies (pp.2-20). Sage Publications Inc.

Dickason, O. \& McNab D. (2009). Canada's First Nations: A history of Founding

Peoples from the earliest times. Oxford University Press.

Durie, M. (2004). Understanding health and illness: research at the interface between science and indigenous knowledge. International Journal of Epidemiology, $33,1138-43$.

Ermine, W. (2007). The ethical space of engagement. Indigenous Law Journal, 6, 193-203.

Ermine, W., Sinclair, R., \& Jeffrey, B. (2004). The ethics of research involving Indigenous Peoples. Indigenous Peoples' Health Research Centre.

First Nations Health. (2020). First Nations researchers use 'two-eyed seeing' to improve Indigenous children's health. First Nations Newsletter. https://www.fnha.ca/about/news-andevents/news/researchers-use-two-eyedseeing-to-improve-indigenous-childrenshealth

Fontaine, L.S., Woods, S., Forbes, L., Schultz, A. (2019) Listening to First Nations womens' expressions of heart health: mite achimowin Digital Storytelling Study. International Journal of Circumpolar Health,78(1). 1630233, DOI: 10.1080/22423982.2019.1630233 
Gathering Strength: Canada's Aboriginal Action Plan. (1997). Ottawa; Minister of Indian Affairs and Northern Development. http://publications.gc.ca/collections/collec tion_2012/aadnc-aandc/R32-189-1997eng.pdf

Goodman, A., Fleming, K., Markwick, N., Morrison, T., Lagimodiere, L., et al. (2017).“They treated me like crap and I know it was becasue I was Native": The healthcare experiences of Aboriginal Peoples living in Vancouver's inner city. Social Science \& Medicine, 178, 87-94.

Henry, F. \& Tator, C. The color of democracy: Racism in Canadian society. Toronto: Thompson Nelson.

Hopper, T. (2018). Here is what Sir John A. Macdonald did to Indigenous People. The National Post, August 28, 2018.

Horrill, T., McMillan, D.E., Schultz, A.S.H., \& Thompson, G. (2018). Understanding access to healthcare among Indigenous Peoples: A comparative analysis of biomedical and postcolonial perspectives. Nursing Inquiry, 25(3). https://www.ncbi.nlm.nih.gov/pmc/article s/PMC6055798/ 18

Interview: Lynette Lucas -- Hishukish Tsawalk (Everything is One, Everything is Connected). (2020, March 3). Keeping In Touch. https://www.keepingintouchbc.com/blog/ 2020/3/2/interview-lynette-lucashishukish-tsawalk-everything-is-oneeverything-is-connectednbsp-using-twoeyed-seeing-to-optimize-healthy-earlylife-trajectories-for-indigenous-peoples

Iwama, M., Marshall, M., Marshall, A., \& Bartlett, C. (2009). Two-Eyed Seeing and the language of healing in communityBased research. Canadian Journal of Native Education, 32(21).
Kovach, M. (2009). Indigenous methodologies: Characteristics, Conversations, Contexts. University of Toronto Press.

Latimer, M., Simand, D., Findley, A., Rudderham, S., et al. (2014). Understanding the impact of the pain experience on Aboriginal children's wellbeing: Viewing through a Two-Eyed seeing lens. First Peoples Child and Family Review, 9(1), 22-37.

Linton, J., \& Ducas, A. (2017). A new tool for collection assessment: One library's response to the Calls to Action issued by Canada's Truth and Reconciliation Commission. Collection Management, 42(3-4), 256-279. https://doi.org/10.1080/01462679.2017.13 44596

McGibbon, E. \& Mbugua, J.W. (2019). Race and racialization in health, health care, and nursing education. In M. McIntyre \& C. McDonald (Eds.). Realities of Canadian Nursing, $5^{\text {th }}$ ed, (pp. 16-31). Wolters Kluwer Health, Canada .

McGibbon, E., Malaudzi, M., Didham, P., Barton, A., \& Sochan, A. (2013). Towards decolonizing nursing: The colonization of nursing and strategies to increase the counter-narrative. Nursing Inquiry, 21(3), 179-191.

Miller, J. (Host). (2020, October 28)._Dialogue 4: Two-Eyed Seeing \& Beyond [Audio podcast]. Reconciling Ways of Knowing. https://www.waysofknowingforum.ca /dialogue-4

Martin, D. (2012), Two-Eyed Seeing: A framework for understanding Indigenous and non-Indigenous approaches to health research. Canadian Journal of Nursing Research, 44, 20-41.

Martin, D. E., Thompson, S., Ballard, M., \& Linton, J. (2017). Two-Eyed seeing in research and its absence in policy: Little 
Saskatchewan First Nation Elders' experiences of the 2011 flood and forced displacement. International Indigenous Policy Journal, 8, 4. https://ir.lib.uwo.ca/iipj/vol8/iss4/6/

National Collaborating Centre for Indigenous Health (2018). Challenges for health equity for Indigenous Peoples social determinants health Policy. Government of Canada and Public Health Agency of Canada. https://www.nccih.ca/495/ Challenges in_health_equity_for_ Indigenous_peoples_in_Canada.nccih?id= $\underline{233}$

Peltier, C. (2018). An application of Two-Eyed Seeing: Indigenous research methods with participatory action Research. International Journal of Qualitative Methods, 17, 1-12.

Poole, R. (1972). Towards deep subjectivity. London: Allen Lane, The Penguin Press.

Ratcliffee, S. (Ed.). (2017). Oxford essential quotes-Desmond Tutu 1931-South African Anglican clergyman. Oxford University Press.

Rieger, K.L., Gazan, S., Bennett, M., Buss, M., Chudyk, A.M., Cook, L., Copenace, S., et al. (2020). Elevating the uses of storytelling approaches within Indigenous health research: a critical and participatory scoping review protocol involving Indigenous people and settlers. Systematic reviews, 9(1), 1-9.

Reimer Kirkham, S., Baumbusch, J.L., Schultz, A.S.H., \& Anderson, J.M. (2007). Knowledge development and evidencebased practice: Insights and opportunities from a postcolonial feminist perspective for transformative nursing practice. Advances in Nursing Science, 30, 26-40.

Schultz, A.S.H., Dahl, L., McGibbon, E., Brownlie, R.J., Cook, C., Elbarouni, B., Katz, A., Nguyen, T., Sawatzky, J., et al., (2020). Coronary artery complexity and its influence on mortality and hospitalizations: a retrospective matched-cohort study comparing First Nations and non-First Nations angiography patients. CMAJ Open, 8(4), E685-E694;

DOI:10.9778/cmajo.20190171

Schultz, A.S.H., Sinclaire, M., Linton, J., McGibbon, E., \& Fisher, R.M. (2016). Negotiating pathways between the health evidence we have and the knowledge we need to address the TRC's call for action [Conference session]. 4th Annual Indigenous health Research Symposium: Think Differently, Act Differently: Research to Action, Winnipeg. MB, Canada. November 23; Winnipeg, MB, Canada.

Smith, L. (2012). Decolonizing methodologies: Research and Indigenous Peoples. Otago University Press.

Smylie, Janet. (2015). Approaching reconciliation: Tips from the field. Canadian Journal of Public Health, 106(5), Springer International Publishing, July 2015, pp. e261-e264, doi:10.17269/cjph.106.5262.

Symenuk, M.P., Tisdale, D., Bourque Bearskin, D.H., \& Munro, T. (2020). In search of the truth: Uncovering nursing's involvement in colonial harms and assimilative policies five years post Truth and Reconciliation Commission. Witness: The Canadian Journal of Critical Nursing Discourse, 2(1). https://witness.journals.yorku.ca/index.ph $\mathrm{p} / \mathrm{default} /$ article /view/51

Tait, C. (2008). Ethical programming: Towards a community-centred approach to mental health and addiction programming in Aboriginal communities. Pimatisiwin: Journal of Aboriginal and Indigenous Community Health, 6(30). 
See it. Speak it. Write it. Change it.

Tilburt, J. (2010). The role of worldviews in health disparities education. Journal of General Internal Medicine, 25 Suppl 2(S2), S178-81.

https://www.researchgate.net/publication/ 51442821_The_Role_of_Worldviews_in_ Health_Disparities_Education

Truth and Reconciliation Commission of Canada. (2015a). Truth and Reconciliation Commission of Canada. http://www.trc.ca/about-us.html

Truth and Reconciliation Commission of Canada. (2015b). Calls to Action. http://nctr.ca/assets/reports/Calls_to_Acti on_English2.pdf

Turnbull, D. (1997). Reframing science and other local knowledge traditions. Futures, 29(11).

Vukic, A., Gregory, D., \& Martin-Mesener, R. (2012). Indigenous health research: Theoretical and methodological perspectives. Canadian Journal of Nursing Research, 44(15).

Walker, L.M.B. (2015). Medicine is relationship: Relationship is medicine. In M. Greenwood, S. de Leeuw, N.M. Lindsay \& C. Reading (Eds.), Determinants of Indigenous Peoples' Health in Canada: Beyond the Social, $1^{\text {st }}$ ed., (pp. 244-54). Toronto: Canadian Scholars' Press Inc.

Wright, A., Gabel, C., Ballantyne, M., Jack, S.M., \& Wahoush, O. (2019). Using twoeyed seeing in research with Indigenous People: An integrative review. International Journal of Qualitative Methods, 18. https://journals.sagepub.com/doi/ $\underline{\text { full/10.1177/ } 1609406919869695}$

Wright, A., Gabel, C., Ballantyne, M., Jack, S.M., \& Wahoush, O. (2019). Using two-eyed seeing in research with Indigenous People: An integrative review. International Journal of Qualitative Methods, 18. https://journals.sagepub.com/doi/ full/10.1177/16094069 19869695 